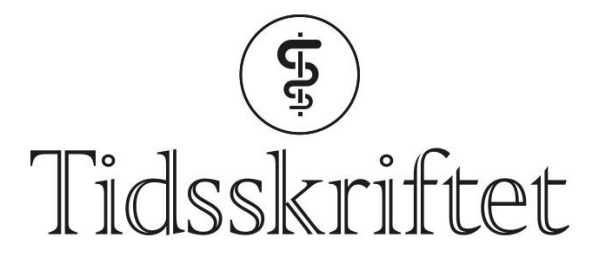

DEN NORSKE LEGEFORENING

\title{
Nyoppdaget mekanisme for muskelregenerasjon
}

FRA ANDRE TIDSSKRIFTER

HAAKON B. BENESTAD

Universitetet i Oslo

Musestudier viser hvordan muskelstamceller, dvs. satellittceller, kan stimuleres til reparasjon av muskelskade.

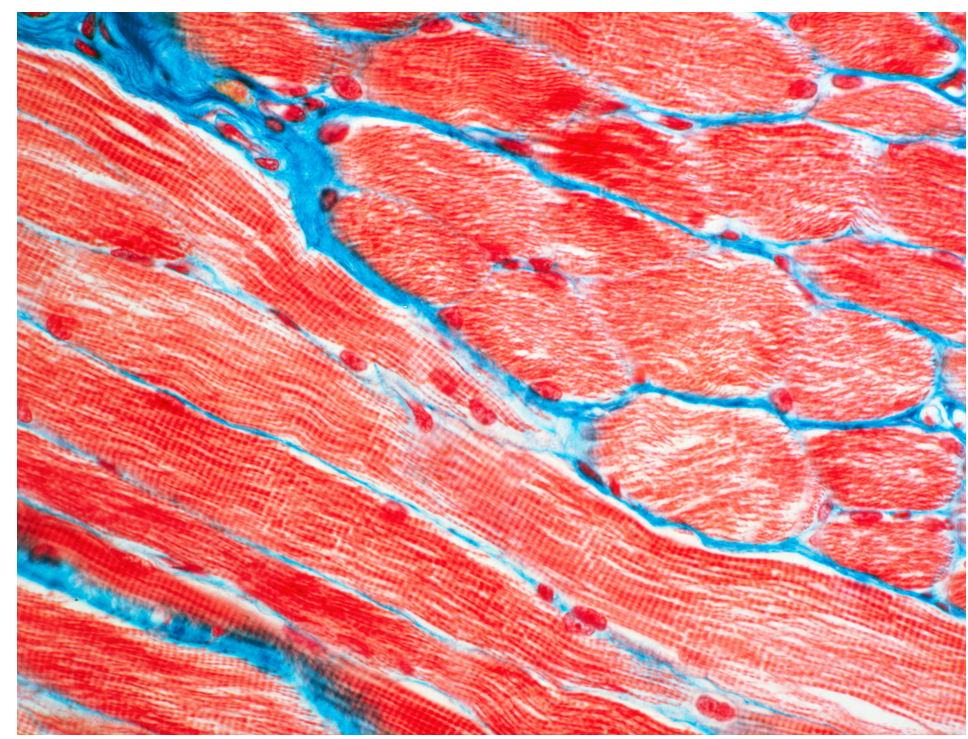

Illustrasjonsfoto: Science Photo Library/ NTB Scanpix

Stamceller påvirkes av andre celler i deres umiddelbare nærhet, som utgjør en såkalt stamcellenisje. I en ny studie fant man at fibroadipogene progenitorceller i denne nisjen utskiller et velkarakterisert protein, WISP1, som trengs for at satellittcellene skal dele seg og noen av dem differensiere og smelte sammen med tverrstripede muskelceller når skader på muskelvev skal repareres (1). Gamle mus hadde både flere muskelskader og færre fibroadipogene celler enn de yngre musene og utskilte mindre WISP1-protein. I mus som manglet genet for WISP1-proteinet, såkalte knockoutmus, fant man at den vanlige reparative reaksjonen fra satellittcellene uteble. Andre celler, bl.a. makrofager og endotel, ble ikke affisert av mangel på WISP1-protein. Infusjon med WISP1-protein til gamle mus førte til økt celledeling blant satellittceller og større regenererende muskelfibre.

- Dette er en meget grundig studie av hvordan aldrende fibroadipogene progenitorceller kan påvirke satellittcellefunksjonen, sier professor Truls Raastad ved Norges idrettshøgskole. Men det er for tidlig å konkludere med at endret WISP1-produksjon er så 
sentral som det antydes. Ofte finnes det kompenserende mekanismer.

- Det er ikke mye muskelskader ved normal trening, så det er omdiskutert om muskelskade spiller en rolle for normale treningstilpasninger. Men uvettig trening fører til muskelskader, sier Raastad, som er skeptisk til om tilførsel av WISP1-protein til yngre som driver med godt fungerende styrketrening, vil forsterke effekten.

- Det er sjelden at behandling med ett enkelt protein løser en fundamental utfordring, slik som ved aldring, og i alle fall ikke uten betydelige bivirkninger. Regelmessig bruk av musklene har god virkning på satellittcellefunksjon hos eldre og er helt fri for bivirkninger. I tillegg gir muskelbruk mange andre positive effekter på aldrende musklers funksjon.

\section{LITTERATUR:}

1. Lukjanenko L, Karaz S, Stuelsatz P et al. Aging disrupts muscle stem cell function by impairing matricellular WISP1 secretion from fibro-adipogenic progenitors. Cell Stem Cell 2019; 24: 433-446.e7. [PubMed][CrossRef]

Publisert: 9. september 2019. Tidsskr Nor Legeforen. DOI: 10.4045/tidsskr.19.0318

(C) Tidsskrift for Den norske legeforening 2020. Lastet ned fra tidsskriftet.no 